\title{
Molecular identification of local field isolated fowl pox virus strain from Giza governorate of Egypt
}

\author{
Susan S. El-Mahdy ${ }^{1}$, M. H. H. Awaad ${ }^{2}$ and Y. A. Soliman ${ }^{1}$
}

1. Central Laboratory for Evaluation of Veterinary Biologics (CLEVB),-El-Seka El-Baida St-Abbasia 131,Cairo, Egypt; 2. Department of Poultry Diseases, Faculty of Veterinary Medicine, Cairo University, Giza, Egypt. Corresponding author Susan S. El-Mahdy, email: prof.s.elmahdy@gmail.com

Received: 12-11-2013, Revised: 25-12-2013, Accepted: 02-01-2014, Published online: 13-02-2014

doi: $10.14202 /$ vetworld.2014.66-71

How to cite this article: El-Mahdy SS, Awaad MHH and Soliman YA (2014) Molecular identification of local field isolated fowl pox virus strain from Giza governorate of Egypt, Veterinary World 7(2): 66-71.

\begin{abstract}
Aim: Molecular identification of field isolated pox virus from infected chickens in Egyptian farms in 2012 by polymerase chain reaction (PCR).

Materials and Methods: Isolation and identification of fowl pox virus (FPV isolate ch-08TK) from 30 day-old chickens manifesting pox lesions. The isolate was propagated successfully on chorioallantioc membrane of specific pathogen free (SPF) embryonated chicken eggs and clear pock lesions were observed. These lesions were homogenated and used to infected SPF chickens and pigeons (via wing web route for chickens and via feather follicle route into the thigh of pigeons) using $10^{4.5}$ $\mathrm{EID}_{50} / \mathrm{mL}$; uninoculated birds of each species were used as negative controls for determining the effect of isolated FPV strain.

Result: The isolated strain gave pathogenic takes $100 \%$ in chickens and $75 \%$ in pigeons. Virus identification by PCR was done using dream Tag master mix kit using the primers that targeted thymidinekinase (TK) gene. These primers were designed using Lasergene DNASTAR software Version 10. We used these primers to amplify a $305 \mathrm{bp}$ fragment of the TK gene of FPV. Phylogenetic analysis of sequenced TK amplicone which reflects a new emerging isolate of the field isolated FPV gave very limited similarity (not exceeding 60\%) with the published sequences. Thus FPV isolate ch-08 TK gene (with Accession No. KF314718 in Gen Bank) is different than canary, Egypt, 2012, P4b and Elsharqyia-FWPV2 FPV140 (FPV140); TKPV FPV140 (FPV140) and PGPV FPV (FPV140) which have been isolated from cases of avipox virus in 2011 from skin crust of different domesticated birds reared under the Egyptian backyard management system. Our sequencing and phylogenetic analysis of newly isolated virus using DNASTAR software Version 10 revealed that this virus differ from canary, Egypt, 2012, P4b and Elsharqyia-(FWPV2 FPV140 (FPV140); TKPV FPV140 (FPV140) and PGPV FPV (FPV140)) according to published data in Gen Bank.
\end{abstract}

Conclusion: FPV (isolated ch-08 TK gene with Accession number KF314718 in Gen Bank) was isolated from 30 day old laying chickens suffering from pox lesions. We believe that this study is the first molecular identification of FPV strain from laying chickens in Egypt.

Key words: Egypt, fowl pox virus strain, local field isolate, molecular identification.

\section{I ntroduction}

Avipox virus (APV) infection is a highly contagious disease of birds and has been reported in more than 200 species of birds and affects domesticated and freeranging birds around the world [1]. APV infection is caused by a large DNA virus that belongs to the genus Avipox virus within the subfamily Chordopoxvirinae in the family Poxviridae [2]. Pox viruses are different from other DNA viruses in that the viruses replicate and mature in the cytoplasm of the infected cells [3]. Wild birds $[4,5]$ and insects [6] play an important role in the spread of pox infection. The DNA of fowl pox virus (FPV) contains approximately 288 to 300 kilo base pairs (Kbp) [2,7]. The shape of pox viruses resemble around brick [8]. It is slow spreading and is characterized by formation of proliferative lesions and scabs (dry form) on skin, and diphtheritic lesions (wet form) in the upper part of digestive and respiratory tracts [2].

Copyright: The authors. This article is an open access article licensed under the terms of the Creative Commons Attribution License (http://creativecommons.org/licenses/by/2.0) which permits unrestricted use, distribution and reproduction in any medium, provided the work is properly cited.
Fowl pox (FP) is of considerable economic importance as the disease can result in a drop in egg production, or retarded growth in younger birds. The chances of mortality increase when the dry form occurs together with the wet form [9]. The general signs of the diseases include weight loss, loss of feathers and scaly skin of the head, neck and back. Secondary bacterial infections are common with both forms of the disease, having the potential to cause pneumonia or other bacterial infections at the site of blistering [5]. Integration of reticuloendotholiosis virus (REV) sequences has been observed in the genome of FPV $[10,11]$. Virulence is enhanced by the presence of REV provirus in the genome of field strains of FPV. Complete sequence of the genome of a vaccine-like strain of FPV has been determined $[7,12]$. The virus tends to persist in the poultry environment for extended periods of time where other viruses may not survive. In this regard the presence of photolysis gene and A-type inclusion body gene in the virus genome appear to protect the FPV from environmental insults $[13,14]$. Antigenic cross reactivity is observed among APVs and it appears that 
many genes are conserved. Restriction fragment length polymorphism (RFLP) analysis can be used for comparison of field isolates and vaccine strains of FPV $[15,16]$. Cloned genomic fragments of FPV can be used effectively as nucleic acid probes for diagnosis of fowl pox. Viral DNA isolated from lesions can be detected by hybridization either with radioactively or nonradioactively labeled genomic probes [17]. Genomic DNA sequence of various sizes can be amplified by the polymerase chain reaction (PCR) [17,18]. PCR technique is very sensitive, especially when small amount of virus in present in the sample [7].

Our study was planned for molecular identification of field isolated pox virus from infected chickens in Egyptian farms in 2012 by PCR using specific primers.

\section{Materials and Methods}

Sample collection: Nodular lesions were collected aseptically from a commercial layer chicken flock in Giza governorate at end of 2012. The flocks have nodular lesions on the combs; corners of the mouth and around the eyelids. The lesions started from $19^{\text {th }}$ day of age and with $10 \%$ mortality rates; these lesions persisted in the flock till 30 day of age. There was no history of previous pox vaccination in this flock.

Virus isolation using embryonated SPF eggs $[19,20]$ : Nodular lesions from infected birds were removed with sterile scissors and forceps by cutting deep into the epithelial tissue. The materials are ground and the $10 \%$ W/V tissue homogenates were prepared in Hank's balanced salt. Suspension is centrifuged for $10 \mathrm{~min}$ at about $700 \mathrm{Xg}$. to remove the large tissue particles. Antibiotics (penicillin \& streptomycin) were added to the supernatant to give respective final concentrations of $1000 \mathrm{IU} / \mathrm{ml}$ and $1 \mathrm{mg} / \mathrm{ml}$. The suspension was held at room temperature $\left(25^{\circ} \mathrm{C}\right)$ for $30 \mathrm{~min}$. About $0.1 \mathrm{ml}$ of suspension was inoculated onto the chorioallantoic membranes (CAMs) of 10-12 day- old SPF embryonating chicken eggs obtained from SPF production farm; Koum Osheim; El-Fayoum, Egypt. This farm is a part of the Ministry of Agriculture. Inoculated embryos were incubated at $37^{\circ} \mathrm{C}$, observed and candled for 5 days. Five non inoculated eggs were kept as negative controls. Five days post inoculation; CAMs were cut, opened and the white pock lesions and generalized thickening areas were collected, pooled and used for further passages on CAMs.

Virus titration: Titration of Fowl Pox isolate was performed in SPF emberyonated chicken egg (ECE) [21]. Ten-fold serial dilutions of isolate were obtained and 5 embryos (10-12 days old) used for dilution were inoculated with $0.2 \mathrm{ml}$ in PBS with $\mathrm{pH} 7.2$ via the CAM route. All deaths within 24 hours post inoculation were not considered. The survived embryos were examined for evidence of infection. Demonstrated pock lesions or generalized thickening of the CAM, on the $5^{\text {th }}$ day post inoculation $\mathrm{ID}_{50}$ was calculated as described earlier [22].
Pathogenicity test: Pathogenicity test was carried out as per method described by AAAP [23] for determining the effect of isolated FPV in different species. 25SPF chickens and 20 pigeons (28 days old) were inoculated with $10^{4.5} \mathrm{EID}_{50} / \mathrm{ml}$ via wing web route for chicken and via feather follicle route in the thigh to pigeons. Five birds per each species were left without inoculation as negative control. All birds were examined for takes formation in case of chickens and for thickening of skin of the thighs in case of pigeons at inoculation site at $3^{\text {rd }}$ to $10^{\text {th }}$ day post inoculation. Additionally, birds were examined for any deaths or symptoms related to avian pox virus.

Virus purification and DNA extraction: The procedure for virus purification was as detailed earlier [24]. After observation of white pock lesions on CAMs in infected SPF eggs with nodular lesions; these CAMs were scrapped into the fluid Tris-EDTA (TE pH 8.0) and pelleted by centrifugation at $5000 \mathrm{Xg}$ for $30 \mathrm{~min}$. The pellet was suspended in $1 \mathrm{~m}$ M Tris-HCL pH 8.0 and sonicated at $80 \%$ amplitude in an ultrasonic disintegrator five times for $10 \mathrm{~s}$ with intervals of $30 \mathrm{~s}$. The supernatant was collected by low speed centrifugation and-suspended in proteinase $\mathrm{K}$ buffer and digested with proteinase $\mathrm{K}(1 \mathrm{mg} / \mathrm{mL})$ at $37^{\circ} \mathrm{C}$ for 2h. The viral DNA was extracted according to the standard procedures by using Mega DNA extraction kit (Biobasic Cat \# 00086242) according to the manufacture procedures.

Virus identification by PCR: The CAMs collected at 5 days post inoculation in SPF eggs were serially diluted and used in reverse transcriptase PCR (RT-PCR). Specific primers were chosen accordingly to the TK gene sequence of an FPV strain [25]. Direct PCR was done using dream Taq master mix Kit (Fermantase cat\#00041067) using the primers that target thymidine kinase (TK) gene These primers were designed using Lasergene DNASTAR software Version 10. The amplicons were electrophoresed on a $1 \%$ agarose gel and visualized under a U.V. transilluminator. A 305 bp fragment of TK gene FPV was amplified. The primer pair designated and had the following sequences:

FP-F 5-TAG-AAG-CAT-CCA-TGT-TAT-TACA-3

FP-R 5-GTT-AAG-CGC-GGC-CAC-AA-AC-3'

Acommercial FPV was used as positive controls in PCR.

DNA sequencing: The complete nucleotide sequence of the amplicon was performed in (Macrogen USA). For preparation of the gene for sequencing, the PCR product was separated on $1 \%$ low melting agarose. The bands were sliced off and purified with the biospin PCR purification kit (Biobasic cat \# BSC03S1) as described by the manufacturer. Sequencing reactions were performed in a MJ Research PTC-225 Peltier Thermal Cycler using ABI PRISM 3730XL Analyzer BigDyeTM Terminator Cycle Sequencing Kits with AmpliTaq DNA polymerase (FS enzyme Applied Biosystems), Sequencing Technology (Sanger dideoxy sequencing). 


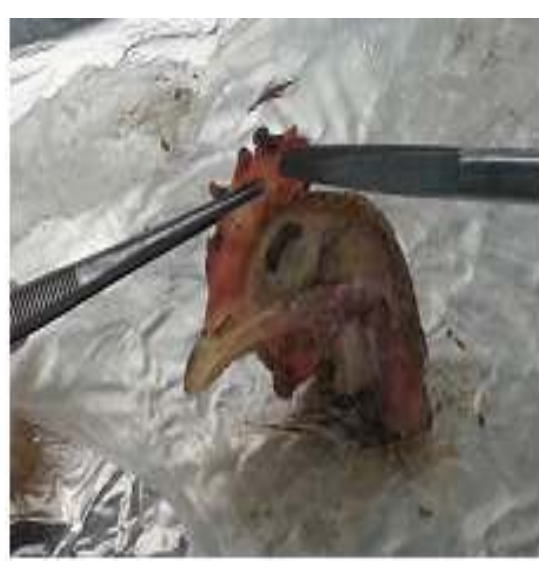

Figure-1. Head of the infected chicken: Notice that infected head showing crusts formation on the comb and on the eyes.

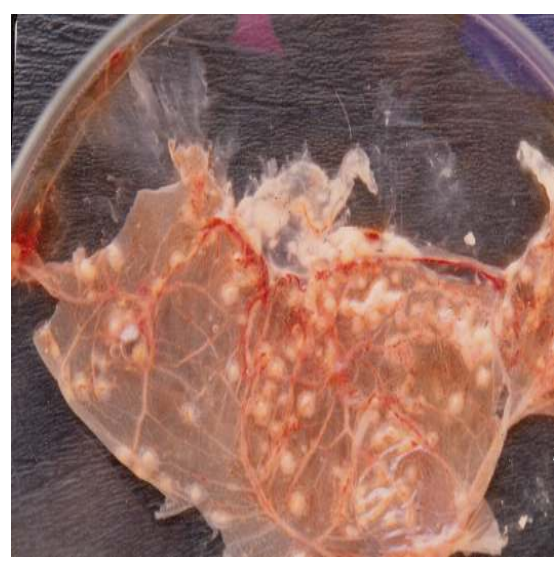

Figure-2. CAM of SPF embryonated chicken eggs inoculated with supernatant fluid of samples collected from infected chicken: Notice that focal white opaque pocks with a generalized thickening of the inoculated CAM with supernatant fluid of samples collected from infected chicken.

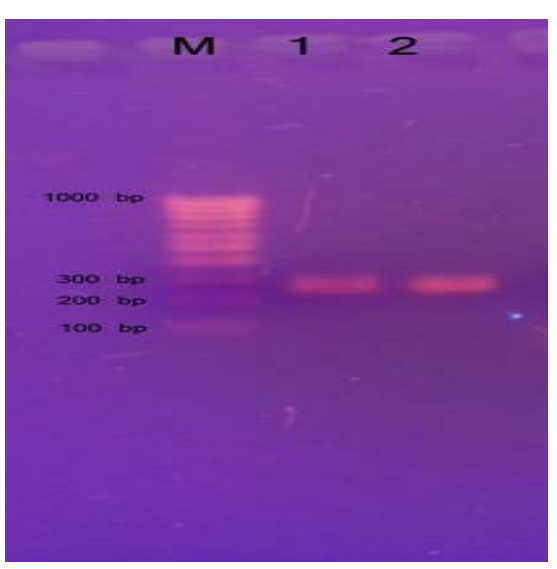

Figure-3. PCR of genomic DNA extracted from Pock lesion: PCR amplification: A $305 \mathrm{bp}$ length amplicon was amplified either from the crusts or the propagated virus on CAM. The amplified TK conservative region from either the crusts (Lane 1 ) or propagated virus on CAM (Lane 2). Note that the amplicons migrate at about $305 \mathrm{bp}$. M a $100 \mathrm{bp}$ DNA ladder.
Phylogenetic analysis: The nucleotide sequence analyses and construction of the phylogenetic trees were performed using Lasergene DNASTAR software Version 10.

\section{Results}

Egg passage: After Passage in SPF embryonated eggs, lesions on CAMs were observed in the form of focal white opaque pocks with a generalized thickening of the CAM (Fig.2).

Virus titration: Isolated pox virus has $10^{4.5} \mathrm{EID}_{50} /$ dose.

FowI pox DNA extraction and detection of DNA of FPV strains: Following proteinase $\mathrm{K}$ digestion of the purified virions the extracted FPV DNA from a representative strain VI was treated with Eco R1 and was separated on a 1-2 \% agarose gel. The extracted DNA was identified as the FPV genome and used for detection of FPV strains using PCR. A DNA fragment with a length of $305 \mathrm{bp}$ was amplified from FPV strain in accordance with the reaction cycle (Fig. 3).

Virus specificity and sensitivity: PCR of FPV strain VI was carried out by applying the primer set for testing the specificity of detection of viral DNA.

Uninfected CAMs were used as negative control and total nucleic acids extracted from CAMs containing FPV were used as positive control. The results showed that no fragment could be amplified with the nucleic acids from any of control cells, however, it could be detected with the nucleic acids extracted from the FPV strain VI.

To assess the sensitivity of detection viral DNA by PCR of a fragment of size 305bp was simplified in a serial 10-fold dilution of infected CAMs with strain VI. After electrophoresis, specific bands of expected size were visible in the sample.

Phylogenic analysis of Avipox viruses TK gene: The isolated strain from layer chicks is shown in (Fig.4-6).
Pathogenicity test: Inoculation of the isolated virus in SPF chickens revealed that about $100 \%$ showed takes at fourth day post inoculation at the sites of inoculation. While 15 of the inoculated pigeons showed thickening of the thighs at sites of inoculation in pigeons neither negative control chickens nor pigeons showed lesions, symptoms related to avian pox infection.

\section{Discussion}

Genus Avipox includes FPV or FWPV; Pigeons Pox Virus (PPV); Turkey Pox virus (TKPV); Canary Pox virus (CNPV); penguin pox virus (PEPV) and other species [26]. Fowl pox has a world-wide distribution and is caused by a DNA virus of the genus Avipox viruses of the family poxviridae [2]. It is a slow spreading virul disease of chickens. All avian species are susceptible to avian pox-as indicated by the fact that natural pox infections have been reported in several species; wild birds of different families as well as in domestic birds [5,27,28]. Most of field strains contain REV provirus. Virulence of virus is enhanced by presence of REV provirus in the genome of field strains of FPV. Restriction fragment length polymorphism (RFLP) analysis can be used for comparison of field isolates and vaccine strains of FPV [29]. DNA of FPV can be detected successfully by using PCR $[25,30]$.

Virus isolation: In this study, poxvirus was isolated on CAMs of SPF chicken egg and further identification was carried out by PCR and sequencing. This technique is useful when there is only extremely small amount of viral DNA in the sample [21]. Sample collection was carried out according to [2]. Lesions detected in Egyptian farms in 2012 in our study agree with previously reported study [31] which isolated FPV from one month old local breed chickens in Grenada with gross lesions in the skin of the head region. Virus isolation on CAM was done [21] and we observed focal white opaque pocks with a generalized 


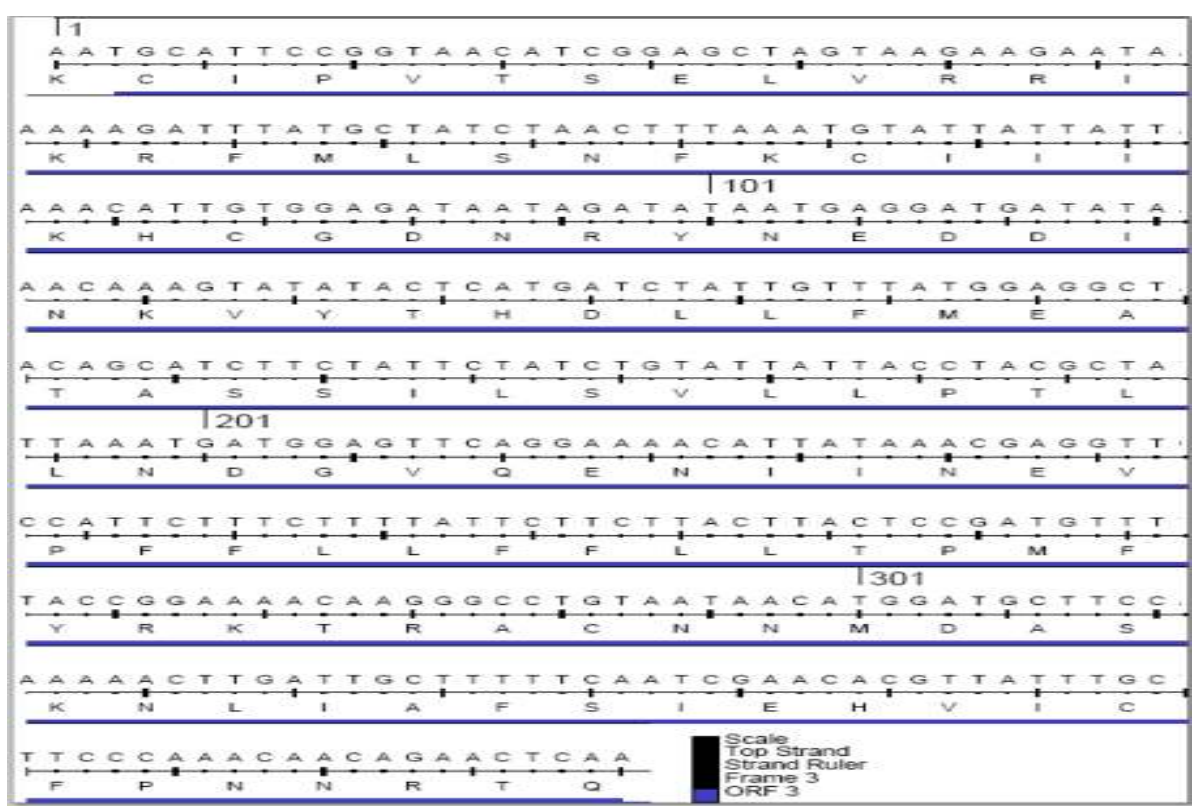

Figure-4. Phylogenetic analysis of Avipoxviruses TK gene. Notice the sequence analysis of the TK gene of the field isolate of FPV

\begin{tabular}{|c|c|c|c|c|c|c|c|}
\hline & Description & $\begin{array}{l}\text { Max } \\
\text { score }\end{array}$ & $\begin{array}{l}\text { Total } \\
\text { score }\end{array}$ & $\begin{array}{l}\text { Query } \\
\text { cover }\end{array}$ & $\begin{array}{c}\mathrm{E} \\
\text { value }\end{array}$ & $\begin{array}{l}\text { Max } \\
\text { ident }\end{array}$ & Accession \\
\hline Vv & Fowlpox virus (isolate HP-438[Munich]), passage 438 clone FP9, complete genome & 370 & 370 & $60 \%$ & $5 e-99$ & $95 \%$ & A 2581527.1 \\
\hline v & Fowlpox virus thymidine kinase gene, complete cds & 370 & 370 & $60 \%$ & $5 e-99$ & $95 \%$ & AF396867.1 \\
\hline Fv & Fowlpox virus, complete genome & 370 & 370 & $60 \%$ & $5 e-99$ & $95 \%$ & AF198100.1 \\
\hline Iv & Fowlpox virus strain HP-440 DNA, isolate FP9, $14.6 \mathrm{~kb}$ fragment & 370 & 370 & $60 \%$ & $5 e-99$ & $95 \%$ & A 2223385.1 \\
\hline V & Fowlpox virus thymidine kinase gene, complete cds & 370 & 370 & $60 \%$ & $5 e-99$ & $95 \%$ & $\underline{M 16617.1}$ \\
\hline Fy & Fowlpoxvirus genes for unknown ORF and thymidine kinase, complete cds & 370 & 370 & $60 \%$ & $5 e-99$ & $95 \%$ & D00321.1 \\
\hline Fv & Fowlpox virus vaccine strain thymidine kinase gene & 370 & 370 & $60 \%$ & $5 e-99$ & $95 \%$ & $\underline{\times 52860.1}$ \\
\hline V & Fowlpox virus nonfunctional thymidine kinase gene, partial sequence & 318 & 318 & $54 \%$ & $2 \mathrm{e}-83$ & $94 \%$ & FJ986112.1 \\
\hline$\sqrt{\vee}$ & Fowlpox virus TK gene for thymidine kinase & 73.1 & 272 & $38 \%$ & $2 \mathrm{e}-09$ & $100 \%$ & $\underline{x 12700.1}$ \\
\hline
\end{tabular}

Figure-5. The blast search analysis of the sequenced TK amplicon of the field isolated FPV. Notice that there is a very limited similarity (not exceeding $60 \%$ ) with the published sequences.

thickening of the CAM (Fig. 2). Similar results have been previously reported with variable levels of thickening, ranging from mild to severe, in CAMs infected with avian pox virus isolated from Italy [32]. There have been many reports that describe differences in growth characteristics of the orthopoxviruses and factors that influence poxvirus growth on CAMs which include incubation temperature, age of the embryos and the source of eggs; so the variability in pock color has also been ascribed to mutation of specific viral genes. [33].

Extraction and detection of DNA: Results of extraction and detection of DNA of FPV strains which gave a fragment of 305bp (Fig. 3) agree with that reported by other authors where application of the PCR for the diagnosis of FPV infection gave a positive 578bp fragment [34] and with others who also used PCR for identification and characterization of FPV strain $[11,35]$. Data obtained by others [30] also adds more support to our results.

Specificity and sensitivity of FPV: Our results agree with previous studies [36-38]. Based on the definition, at least one infectious unit is required for the isolation of virus, indicating that PCR may also detect noninfectious virus particles present in the sample preparations. In addition, this primer set appears to be specific for FPV DNA, because it did not amplify the DNA sequences of nucleic acid preparation from uninfected tissue. Furthermore, nucleic acid extracted from unrelated pox virus was not amplified with this primer set. Thus, PCR seems to be rapid, specific and highly sensitive and could become a powerful tool for the detection sensitivity of FPV infections [34].

Pathogenicity test: Inoculation of the isolated virus into SPF chickens revealed that about $100 \%$ showed takes at fourth day post inoculation in wing web sites of inoculation, while $75 \%$ of the inoculated pigeons showed thickening of the thighs (sites of inoculation in pigeons). In addition, neither negative control chickens nor pigeons showed lesions or symptoms related to avian pox infection. These results indicate that the isolated strain is more related to chicken than pigeon. 


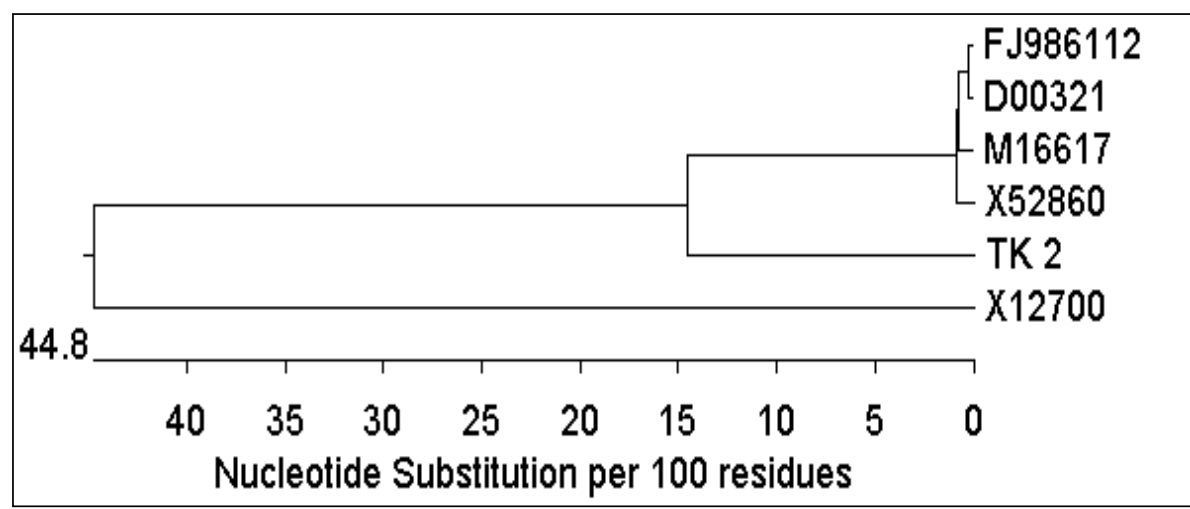

Figure-6. The phylogenetic tree analysis of the sequenced TK amplicon of the field isolated FPV.

Phylogenic analysis of Avipox viruses TK gene: Our results are different from that previously reported on inoculation of canary, Egypt, 2012, P4b virus in SPF chickens where 7out of 15 chickens (about 46\%) showed takes at $3^{\text {rd }}$ day post inoculation into the wing web; while none of the inoculated pigeons showed thickening of the thighs at the sites of inoculation in pigeons [39]. Therefore, in this study as well as in others $[25,32,33,40]$, APVs from the same species of bird are classified in different sub clades. Conversely, it has also been shown that the same viruses can infect different birds. By using phylogenic analysis; the strains isolated in the present work showed homology to the PCR products of chicken sample on purification and sequencing (Fig 4-6). A common sequence of nucleotides was obtained, allowing comparison with equivalent previously published sequences in the Gen Bank. The derived and aligned nucleotides sequences were used to generate a phylogenetic tree for Pub encoding sequence with other 9 Avi poxviruses with TK gene. So that there is a very limited similarity (not exceeding 60\% with (AJ581527 [41]; Af396867; Af198100 [42]; AJ223385[43]; M16617[44]; D00321 [45]; X52860 which isolated at 2003; 2001; 1999; 1987;1987;1988;1990 from Germany; India; USA; UK and USA ; respectively) and $55 \%$ with Fj986112 [46] which isolated at 2008 from Grenada and with X12700[47] which isolated from Australian at 1987 with very minute similarity (38\%) (Fig.5).

\section{Conclusion}

FPV (FPV isolated ch-08 TK gene with Accession KF314718 in Gen Bank) which is isolated from laying chicken aged 30 day old and suffering from pox lesions were different from avian pox like lesions which-were observed from canary in Egypt in 2012 (Canary/ Egypt/2012/p4b) [39]; and from that isolated six clinical cases of avipoxvirus at 2011 from skin crust of different domesticated birds reared in the Egyptian backyard mangment system [40] and were propagated on CAMs of embryonated chicken eggs and virus isolation was confirmed via PCR as ElsharqyiaFWPV2 FPV140(JX464823); TKPV FPV140 (JX 464 826) and PGPV FPV(JX464827). Thus, according to our knowledge this study is considered as the first molecular identification of FPV strain from laying chickens in Egypt.

\section{Authors' contributions}

MHHA was responsible for collection of samples from commercial layer chicken flocks in Giza governorate at end of 2012. YAS did the PCR identification and phylogenic analysis. SSEM did the virus isolation, titration, pathogenicity, drafted and revised the manuscript. All authors read and approved the final manuscript.

\section{Ackowledgements}

The authors are grateful for Central Laboratory for Evaluation of Veterinary Biologics, Abbasia, Cairo, Egypt for funding this work.

\section{Competing interests}

The authors declare that they have no competing interests

\section{References}

1. Hye Jeong Ha, Maurice Alley, Laryssa Howe and Brett Gartrell. (2013) Evaluation of the pathogenicity of avipoxvirus strains isolated from wild birds in New Zealand and the efficacy of a fowl pox vaccine in passerines. Vet. Microbiol.165(3-4):268-274.

2. Tripathy, D.N. and Reed W.M (2008) Pox, In A laboratory manual for the Isolation, Identification and characterization of avian pathogens. 5th Edn. American Association of Avian pathologists Ch. 5 : 116-119.

3. Wangner,E.K.,Hewlett,M.J.,Bloom,D.C. and Camerini,D. (2008) Basic virology. Blackwell Pub.,Malden,MA,pp.97137,359-379,435-495.

4. Atkinson, C.T. and La Pointe, D.A. (2009) Introduced avian diseases, climate change, and the future of hawailian honeycreepers. J. Avian Med. Surg.23, 53-63.

5. Parker,P.G., Buckles, E.L., Farrington,H., Petren,K., Whiteman, N.K., Ricklefs, R.E.,Bollmer,J.L. and JimenezUzcategui, G.(2011):110 years of Avipoxvirus in the GalapagosIslands. PloSone. 6.1:e 15989..

6. VanRiper,C. and Forrester,D.J.(2007) AvianPox. In: Thomas, N., Hunter, D.B., Atkinson, C.T. (Eds.). Infectious Diseases of Wild Birds. Black well publishing Professional, Ames, Iowa, USA, pp.131-176.

7. Afonso C.L., Tulman E.R., Lu Z., Zsak K., Kutish G.F. and Rock D.L. (2000):The genome of fowl pox virus. J. Virol, 74, 3815-3831.

8. Hyun, JK., Accurso, C.1., Hijnen, M., Schult, P., Pettikiriarachchi, A, Mitra, A.K. and Coulibaly, F. (2011) Membrane remodeling by the double-barrel scaffolding protein of poxvirus. PLoS pathog 7: e 1002239.

9. Maclachlan N, dames, and Dubovi, Edwardd (2009) fenner's veterinary virology (4th ed) Amsterdam: Elsevier Academic Press. PP.163. 
10. Singh P., Kim T.J. and Tnipathy D.N. (2000) Re-emerging fowlpox: evaluation of isolates from vaccinated flocks. Avian pathol., 29; 449-455.

11. Singh, P., Kim T.J. and Tripathy D.M. (2003a) Identification and characterization of fowl pox virus strains using monoclonal ant. Bodies. J. Vet. Diag. Invest. 15: 50-54.

12. Singh P. Schnitzlein W. M. \& Tropathy D.N. (2003b) Reticuloendotheliosis virus sequences within the genomes of field strains of fowl pox virus display variability. J. Virol., 77: 5855-5862.

13. Srinivasan V., Schnitzlein W.M and Tripatly D.N. (2001) Fowl pox virus encodes a novel DNA repair enzyme, CPDphotolysis that restores infectivity of UV Light-damaged virus. J. Virol., 75, 1681-1688.

14. Srinivasan V. and Trippathy D.N. (2005) The DNA repair enzyme, CPD-photolyases restores the infectivily of UVdamaged fowl pox virus isolated from infected scabs of chickens. Vet. Microbiol., 108: 215-223.

15. Schnizlein M.W., Ghildyal N. and Tripathy, D.N. (1988) Genomic and antigenic characterisation of avi poxivruses. Virus Res. 10, 65-76.

16. Ghildyal N., Schnitzlein W.M. and Tripathy D.N. (1989) Genetic and antigenic differences between fowl pox and quail pox viruses. Arch. Virol., 106, 85-92.

17. Fallavena. L.C., Canal C.W., Salle C.T., Moraes H.L., Rocha S.L. and Pereira Da Silva A.B.C. (2002) Presence of avipoxvirus DNA in avian dermal squamous cell carcinoma. Avian Pathol., 31;241-246.

18. Luschow, D., Hoffmann, T., \& Hafez, H.M. (2004): differentiation of avian pox virus strains on the absis of nucleotide sequences of the ub gene fragment. Avian Dis 48: 453-463.

19. Hitchner, S.B., Domermuth, C.H., Purchase, H.G. and Willta, J.E. (1980) Virus progagation in embryonating eggs. In. Isolation and Identification of avian pathogens, eds printing company, end well N.Y. 120-121.

20. Bossinger, T.R., Winterfield, R.W., Feldman, D.S. and Dhillon, A.S. (1982) Psillacine pox virus: virus isolation and identification, transmission, and cross challenge studies in parrots and chickens. Avian Dis 26: 437-440.

21. OIE (2012) Office of International des Epizooties, International Health Code. Fowl pox Ch. 2.3.10 531-537.

22. Reed, L.J. and Munch, H. (1938) A simple method of estimating fifty percent end point Amer. J. Hyg. 9., 273-497.

23. AAAP (2008) American Association of Avian pathologists: A Laboratory Manual for the Isolation, Identification and characterization of Avian pathogens 5th edition. USA.

24. Mochett., A.P.A., Southee, D.J, Tomley, F.M. and Deuter, A. (1987) fowl pox virus: its structural proteins and immunogens and the detection of viral-specific antibodies by ELISA. Avian Pathol. (16) 493-504.

25. Ha, H.J., Howe,L., Alley,M. and Gartrell,B. (2011) The phylogenetic analysis of avipoxvirus in New Zealand. Vet. Microbiol. 150: 80-87.

26. Andraw, K. (2012) Virus taxonomy: ninth report of the international committee on the taxonomy of viruses. The international committee on taxonomy of international union of microbiological societies. Pp. 298.

27. Chen ,C.C. , Pei, K.J.C., Lee ,F.R and Zeng, M.P.T. (2011): Avian pox infection in a free living crested serpent Eagle in Southern Taiwan. Avian Dis 55(1) 143-146.

28. Kyung-Yeon Eo, Young-Hoan Kim, Kwang-Hyun Cho, Jong-Sik Jang, Tae- Hwan Kim; Dongmi Kwak and OhDeog Kwon(2011):Infection of Avian Pox virus in Oriental Turtle- Doves. Pak Vet J,31(4):354-356.

29. Ibrahim S. Diallo, Jim Taylor, John Gibson,John Hoad, Amanda De Jong, Glen Hewitson, Bruce G. Corney and Barry J. Rodwell (2010) Diagnosis of anaturally occurring dual infection of layer chickens with fowl pox virus and gallid herpervirus 1(Infectious Laryngotracheitis virus). Avian Pathol 39(1):25-30.

30. Hess, C., Maegdefrau-Pollan, B., Bilic, I., Liebhart, D.,
Richter, S., Mitsch, P. and Hess, M. (2011) Outbreak of cutaneous form of poxvirus on a commercial turkey farm caused by the species fowl pox. Avian Dis. 55(4):714-8.

31. Arathy, D.S., Tripathy, D.N., Sabarinath, G.P., Bhaiyat, M.I., Chikweto, A., Matthew, V. and Sharma, R. N. (2010) Preliminary molecular characterization of a fowl poxvirus isolate in Grenada. Avian Dis, 54(3):1081-5.

32. Manarolla, G., Pisoni, G., Sironi, G. and Rampin, T. (2010) Molecular biological characterization of avian poxvirus strains isolated from different avian species. Vet. Microbiol. 140: $1-8$.

33. Kristy Offerman, Olivia Carulei, Tertius A, Gous, Nicola Douglass \& Anna-Lise Williamson. (2013): Phylogenetic and histological variation in avipoxviruses isolated in South Africa. J. Gen Virol, 94: 2338-2351.

34. Lee, L.H. and Lee, K. H. (1997) Application of the plymerasa chain reaction for the diagnosis of fowl poxvirus infection. J. Virol Methods, 63; 113-119.

35. Jarmin, S., Manvell, R., Gough, R.E., Laidlow, S.M. and Skinner, M.A. (2006) Avipoxvirus phylogenetics: Identification of a PCR length polymorphism that discriminates between the two major clades. J. Gen Virol 87: (2) $191-201$.

36. Siddique, A. B., Hossain, F. M. A. and Zinnah, M. A. (2011) Determination of host specificity of pigeon pox and fowl pox viruses isolated from a field outbreak. Bulgarian Journal of Vet Medicine.14 (4) 209-214.

37. Tadese, T. and Reed, W. M. (2003) Detection of specific reticuloendotheliosis virus sequence and protein from REVintegrated fowl pox virus strains. J. Virol Methods 110:99-104.

38. Luschow, D, Hoffmann, T. and Hafez, H.M. (2004) Differentiation of avian pox virus strains on the basis of nucleotide sequences of $4 \mathrm{~b}$ gene fragment. Avian Dis 48 : 453-62.

39. Abd El-Razek, B. Abd El-Razek, Hanan M. El-Zahed and Sherif M. Ibrahim (2012) Studies on avian Pox-Like lesions in Canary. Zag. Vet. J. 40(5):172-180.

40. Abdallah, F. M. and Hassanin, O. (2013) Detection and molecular characterization of avipoxviruses isolated from different avian species in Egypt. Virus Genes 46: 63-70.

41. Laidlaw,S.M. and Skinner, M.A.(2004) Comparison of the genome sequence of FP9, an attenuated, tissue cultureadapted European strain of Fowl Pox virus, with those of virulent American and European viruses. J. Gen. Virol. 85(2): 305-322.

42. Afonso, C. L., Tulman, E. R., Lu, Z., Zsak, L., Kutish, G. F. and Rock, D. L. (2000) The genome of fowl pox virus. $J$. Virol. 74(8): 3815-3831.

43. Binns, M. M., Stenzler, L., Tomley, F. M., Compbell, J. and Boursnell, M. E. (1987) Identification by a random sequencing strategy of the fowl-pox virus DNA polymerase gene, its nucleotide sequence \&comparison with other viral DNA polymerases. Nucleic Acids Res.15(16),6563-6573.

44. Boyle, D. B., Coupar, B. E., Gibbs, A. J., Seigman, L. J. and Both, G. W. (1987) Fowl pox virus thymidine: nucleotide sequence and relationships to other thymidinekinases. Virology 156(2):355-365.

45. Binns, M. M., Tomley, F. M., Compbell, J. and Boursnell, M. E. (1988) Comparison of a conserved region in fowl virus \& vaccinia virus genomes \& the translocation of fowl pox virus thymidine kinase gene. J. Gen. Virol. 69(6): 1275-1283.

46. Arathy, D. S., Tripathy, D. N., Sabarinath, G. P., Bhaiyat, M. I., Chikweto, A., Matthew, V. and Sharma, R. N. (2010) Preliminary molecular characterization of fowl pox virus isolate in Grenada. Avian Dis. 54(3), 1081-1085.

47. Binns, M. M., Boursnell, M. E. and Skinner, M. A. (1992) Gen translocations in pox viruses: the fowl pox virus thymidine kinase gene is flanked by 15 bp direct repeats \& occupies the locus which in vaccinia virus is occupied by the ribonucleotiede reductase large subunit gene. Virus Res.24(2):161-172.

$* * * * * * * *$ 